\title{
Inspirações anarquistas de Nicanor Parra e Octavio Paz
}

\author{
Sebastião Leal Ferreira Vargas Netto ${ }^{1}$
}

Resumo: Este artigo pretende explorar a presença de inspirações anarquistas na trajetória e na obra de dois intelectuais latino-americanos nascidos no ano de 1914: Nicanor Parra e Octavio Paz. Utilizando suportes documentais variados (depoimentos, ensaios, produção memorialística, cartas, poesias, discursos), refletimos sobre como dois dos mais importantes poetas da sua geração foram influenciados pelas diversas tradições libertárias e como a expressão poética (essa "outra voz") é uma contribuição fecunda para o pensamento crítico e para a história da resistência ao autoritarismo na América Latina.

Palavras-chave: intelectuais latino-americanos; anarquismo; antiautoritarismo

\section{Anarchist inspirations in the work of Nicanor Parra and Octavio Paz}

Abstract: This article aims to explore the presence of anarchist inspirations in the path and the work of two Latin American intellectuals born in the year of 1914: Nicanor Parra and Octavio Paz. Through several documental supports (testimonies, essays, memorial production, letters, poems, speeches), we reflect about how two of the most important poets of their generation were influenced by diverse anarchist traditions and how the poetic expression (this "other voice") is a fruitful contribution to the critic thought and to the history of the resistance against the authoritarianism in Latin America.

Keywords: Latin American intellectuals; anarchism; anti-authoritarianism

Artigo recebido em: 15/01/2021

Artigo aprovado para publicação em: 07/05/2021

1 Doutor em História Social pela Universidade de São Paulo (USP). Departamento de História da Universidade Federal do Rio Grande do Norte (UFRN). E-mail: sebastiao.leal.vargas@ufrn.br 
Pode haver, e realmente há, muitos tipos de anarquistas. O ponto de união é a negação do princípio da Autoridade nas organizações sociais e o ódio a tudo que origina instituições baseadas nesse princípio. Portanto, quem nega a Autoridade e luta contra ela é um anarquista. Sebastien Faure, Enciclopédia anarquista

Como os anarquistas filosóficos e artísticos, há muitas pessoas próximas de nós, mas que recusam a etiqueta de anarquistas, e outras que recusam qualquer etiqueta. Todas elas têm um papel a desempenhar, quando mais não fosse para fornecerem um auditório simpatizante e labutarem pela liberdade no seu entorno. Nicolas Walter, Do anarquismo

\section{Introdução}

O chileno Nicanor Parra (1914-2018) e o mexicano Octavio Paz (1914-1998) são intelectuais latino-americanos cujas vidas, em grande parte, coincidiram com a periodização proposta pelo historiador Eric Hobsbawm (1917-2012) para o curto século $\mathrm{XX}^{2}$. Suas obras, trajetórias e crises podem ser vistas como testemunhos privilegiados das transformações espantosas operadas neste século de extremos. Analisá-las em perspectiva paralela nos ajuda, por exemplo, a revelar o movimento de adesão e desilusão frente às grandes ideologias que mobilizaram não somente intelectuais, mas amplos setores das sociedades convulsionadas pelas revoluções e contrarrevoluções do século. Revela também as relações ambíguas entre setores da intelectualidade latinoamericana e as múltiplas manifestações dos sistemas de poder, quando muitos pensadores oscilaram entre participação engajada, resistência apaixonada e ânsia por independência e liberdade de imaginação frente às arenas ideológicas e contextos políticos polarizados e petrificados.

Inúmeros escritores latino-americanos do século XX se autodefiniram - de modo polêmico - anarquistas exatamente para tentarem expressar essa postura de independência e inquietude intelectual (VARGAS; CAVALCANTE, 2019). No seu clássico estudo Anarquismo en la América Latina (1990), Ángel J. Cappelletti afirma que as influências ideológicas e culturais do anarquismo, em suas mais variadas expressões, foram sistematicamente minimizadas por boa parte da historiografia e

\footnotetext{
2 Para Hobsbawm, o 'breve' século XX se estende da eclosão da Primeira Guerra Mundial (1914) ao colapso da URSS (1991).
} 
crítica acadêmica. Por outro lado, é muito complicado lograr uma definição generalizadora do anarquismo ${ }^{3}$. Todas as tentativas sérias de realizar uma tipologia do anarquismo têm de enfrentar as antinomias e a enorme diversidade de suas modalidades e vertentes (talvez fosse mais adequado utilizar o termo no plural: anarquismos). Como afirma Andrew Vincent (1995), a anarquia parece estar mais sujeita que outras ideologias à pluralidade de pontos de vista (no seu próprio seio) relativas a inúmeras questões, o que torna sua análise muito mais complexa que as de outras ideologias modernas.

Sob muitíssimos aspectos, as obras, reflexões e posturas de Nicanor Parra e Octavio Paz são contrastantes. Talvez por isso mesmo seja interessante lançar luz sobre uma questão relativamente pouco abordada pela crítica: como esses autores avaliam o papel da "tradição libertária e anarquista" no desenvolvimento do seu pensamento e dos seus escritos? Paz é um dos intelectuais mais completos e fecundos das letras latinoamericanas, tendo sido agraciado com o Prêmio Nobel de Literatura em 1990. Sua produção é imensa, sendo virtualmente impossível qualquer tentativa de resumi-la em espaço tão curto: poesia, dramaturgia, crítica, história, ensaio, tradução, edição. $\mathrm{O}$ catálogo de temas abordados nos seus ensaios (sempre em chave-poética e nunca acadêmica) é estonteante: a tradição das rupturas nas vanguardas artísticas; as relações entre mito e história; a obra e o contexto histórico de Sor Juana Inés de la Cruz; antropologia; cultura oriental, democracia e crítica do socialismo autoritário (NETTEL, 2014). Já a obra de Nicanor Parra, muito mais compacta e quase que estritamente antipoética, representa sobretudo uma "atitude anárquica" (ALEGRÍA, 1979, p. 259) de provocação e ironia frente à literatura, ideologia e cultura, bem como uma ânsia sarcástica por desmistificar e ridicularizar aqueles intelectuais (sobretudo os poetas) que arvoravam um estatuto demiúrgico, solene, pomposo, paramístico e especial para si próprios e seus "saberes".

\footnotetext{
${ }^{3}$ Edson Passetti, por exemplo, considera ser "impossível definir o que é anarquismo. Ele é um fluxo de singularidades que coexistem" (2005, p. 22). Se o panorama político-ideológico anarquista é caraterizado por indefinição, fluidez e conflito de posições, o cenário dos anarquismos artísticos e literários tende ser ainda mais instável. Sobre esta temática, ver ainda as obras de André Reszler (2005) e Allan Antliff (2009).
} 
Apesar disso, ambos são exemplos de intelectuais cujas obras, cada uma à sua maneira, representam uma tentativa de recuperar o potencial rebelde da expressão poética. Com intensidades diferentes, cada um foi influenciado por aquilo que eles próprios descreviam como tradição intelectual libertária, anarquizante, anarquista ou mesmo anarcóide ${ }^{4}$ (uma tradição que quer fundir a ética e a estética com a política) bem analisada por Othoniel Rosa (2016) no seu instigante estudo sobre os anarquismos literários de Macedonio Fernández (1874-1952) e Jorge Luis Borges (1899-1986). Uma corrente ampla, contraditória e polêmica, mas que fertilizou o pensamento e sentimento de intelectuais que concebiam a atividade poética (mesmo quando ela deveria tornar-se antipoética ou ensaística) como eminentemente pessoal (solitária e sujeita às contradições) e umbilicalmente ligada à constante busca por independência e crítica às ideologias programáticas e petrificadoras da criatividade e, sobretudo, ao autoritarismo mental. O trecho do poema "Petrificada petrificante" (1975), escrito por Paz, é uma boa ilustração dessa crítica:

\author{
Los cerebros están manchados de tinta \\ Los doctores discuten en la ladronera \\ Los hombres de negocios \\ manos rápidas pensamientos lentos \\ ofician en el santuario \\ Los dialécticos exaltan la sutileza de la soga \\ Los casuistas hisopean a los sayones \\ Amamantan a la violencia con leche dogmática \\ La idea fija se emborracha con el contra \\ El ideólogo cubiletero \\ afilador de sofismas \\ en su casa de citas truncadas \\ trama edenes para eunucos aplicados \\ bosque de patíbulos paraíso de jaulas \\ Imágenes manchadas \\ escupieron sobre el origen \\ carceleros del futuro sanguijuelas del presente \\ afrentaron el cuerpo vivo del tiempo \\ Hemos desenterrado a la Ira $^{5}$
}

\footnotetext{
${ }^{4}$ Nicanor Parra, ao comentar a profunda relação entre suas ideias libertárias e antiautoritárias com o taoísmo que abraçou na década de 1980, varia a autodenominação "anarquista" com "anarcóide" (CARRASCO, 2007, p. 85).

${ }^{5}$ Com exceção deste trecho do poema de Octavio Paz (e de alguns outros), decidi traduzir livremente todos os trechos originalmente em espanhol que constam na bibliografia utilizada.
} 
Os pensamentos e obras de Nicanor Parra e Octavio Paz também devem ser encarados como um esforço por alargar a imaginação de uma outra política que potencialize as possibilidades da democracia, como disse Paz numa entrevista de 1992: “O novo pensamento político não poderá renunciar ao que tenho chamado 'a outra voz', a voz da imaginação poética. A volta dos tempos será o tempo da reconquista daquilo que é irredutível aos sistemas e burocracias: o homem, suas paixões, suas visões" (1995, p. 496). Nas últimas décadas de sua longa vida, Parra refinou suas posições a favor de uma radicalização da democracia por meio de algum tipo de "socialismo aberto, libertário e ecológico" (2012, p. 1030) e alertando para o potencial (alter)nativo da cosmovisão dos povos originários: "Muitos problemas / uma solução / economia mapuche de subsistência” (2012, p. 761). Em 1993, no Discurso del Caupolicán, Parra se autointerroga num diálogo em voz alta (2012, p. 1017)

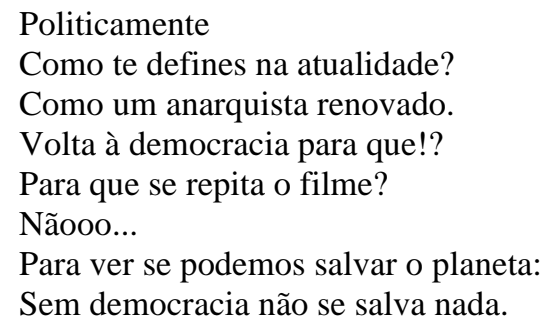

Octavio Paz escreveu muitos ensaios sobre a natureza, história, limites e inimigos da democracia que ele considerava "uma forma política universal que pode ser adotada por todos, com a condição de que cada povo a adapte a seu gênio" (1995, p. $353)^{6}$. Nos seus luminosos e altamente intuitivos textos sobre as filosofias orientais (que vinculava à cosmovisão dos ameríndios e com certa tradição anarquista ocidental), Paz buscava encontrar uma "resposta civilizada e eficaz contra a violência universal desatada em nosso século por ditadores e as ideologias. É uma semente de salvação, como a tradição libertária. A sorte final de ambas está ligada à sorte da democracia" (1995, p 348).

\footnotetext{
${ }^{6}$ Para citarmos apenas três: América Latina y la democracia (1983), Inventar la democracia: América Central, Estados Unidos, México (1985) e La democracia: lo absoluto y lo relativo (1992), todos contidos no nono volume de suas Obras Completas (1995).
} 
Ambos pensadores enxergavam no "anarquismo filosófico e político da corrente intelectual do taoísmo" (PAZ, p. 350) um possível antiveneno ${ }^{7}$ contra os complexos e repressões industriais-militares, o consumismo, o produtivismo (proveniente do mundo capitalista ou socialista) e seu alucinado movimento de devoração "não somente da comunidade humana, da espécie humana, mas de todo o sistema vivo, planetário" (PARRA, 2012, p. 1015). Parra e Paz encontram em certo horizonte espiritual provindo do oriente - a satyagraha de Gandhi, o erotismo tântrico, o satori (do zen), o budismo madhyamika (ao qual Paz esteve à ponto de se converter) e o "anarquismo poético de Lao Tsé e Chuang Tzu” (PAZ, 1995, p. 350) - uma inspiração não somente para sua poesia, pensamento e existência, mas para a crítica afiada tanto do capitalismo ocidental e suas expressões fascistas, quanto para o que Paz chamou de "ditadura burocráticomilitar que, por um colossal equívoco histórico, chamamos de socialismo" (1995, p. 355). Como escreve Parra num ecopoema de 1983:

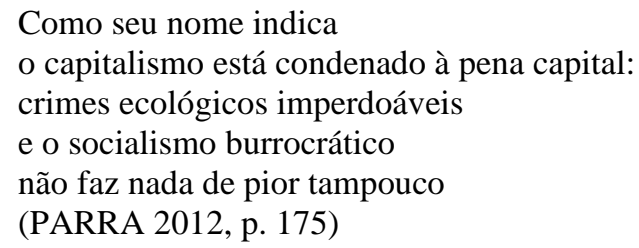

Embora Nicanor Parra, como muitos ecologistas, parecesse acreditar que o pensamento ecológico ou "ecofilosofia" poderia representar o início de certa superação das ideologias do século XX, ele estava ciente do alerta que Paz fez em uma entrevista de 1992: "o discurso ecológico, por razões fáceis de compreender, pode degenerar em demagogia e em manipulação política. As ideologias vencidas regressam à nossas mesas de debates sob a máscara da ecologia” (1995, p. 492). Mesmo assim, Paz considerava que - juntamente ao feminismo - o movimento ecologista era extremamente importante para mudanças de atitude e pensamento em questões que ele

\footnotetext{
7 “O taoísmo é um dissolvente. Não é estranho que os confucionistas o vissem como uma tendência antissocial, inimiga da sociedade e do Estado. No taoísmo há uma persistente tonalidade anarquista" (PAZ, 2000, p. 18).
} 
vinha sustentando durante décadas: a insensata ideia de "dominação" da natureza e os perigos e limites do "progresso". A consciência ecológica (potencializada nas décadas 1980 e 1990) escancara um tema central das reflexões de ambos autores ao longo de suas obras: o fim da modernidade e de sua visão de tempo como um processo linear e identificado com um movimento ascendente da história.

As expressões antipoética e poética de Nicanor Parra e Octavio Paz (com todas suas evidentes diferenças) podem ser lidas como uma urgência para encontrar meios de se posicionar e pensar sobre as incertezas da condição contemporânea: "assistimos ao crepúsculo da religião do futuro, sol do progresso. Vivemos o fim da modernidade e o começo de outro tempo" (PAZ, 1995, p. 495).

\title{
O tao de Nicanor Parra: franco-atirador anarquista
}

\begin{abstract}
Eu estive a ponto de me converter ao comunismo... E depois veio o Golpe, veja você, e veio a ruptura também, ainda na época da Unidade Popular. Eu votei em Allende, mas veio a ruptura e então eu tive de me olhar no espelho, porque disseram que eu era o palhaço da burguesia. Então me pus a estudar e me declarei, sentei praça de anarquista. Eu iria me defender, não a partir do capitalismo, mas desde o anarquismo. E então estudei - como estava dizendo - o processo do golpe militar com as ideias anarquistas na cabeça. A partir de várias considerações de ordem anarquista, eu fiquei, em vez de ir embora. E então depois do anarquismo, também percebi que eu estava mais próximo do taoísmo do que de qualquer outra coisa. Porque o taoísmo, se você olhar para ele com uma lupa, é uma doutrina libertária, quase que no sentido anarquista Nicanor Parra em entrevista para Iván Carrasco (2007, p. 85)
\end{abstract}

Na origem da antipoesia de Nicanor Parra (década de 1950) estava seu trabalho com a cosmologia e os princípios da física quântica: a indeterminação, a descontinuidade da realidade e o "humorismo sangrento da teoria da relatividade", como escreve no antipoema "Os vícios do mundo moderno". Mergulhado em seu trabalho com átomos, Parra afirma que se acostumara a pensar em termos de prótons e elétrons, em cargas positivas e negativas, algo e seu contrário. Ele pressentiu que deveria levar esses princípios de relatividade, indeterminação e polaridades aos campos da literatura e da poesia (e também da política, cultura e do debate público). Parra vincula o anarquismo a esses princípios da física que deveriam ser projetados no campo político: "Imagine que sequer podemos prever o comportamento de uma partícula, 
muito menos podemos prever o que ocorrerá com a comunidade humana, que é tão mais complexa" (2012, p. 1030).

Tributário da (anti)tradição do Dada, Nicanor Parra considera que a realidade é um absurdo que se crê lógico. A poesia merece ser ridicularizada quando se apresenta como discurso sublime e solene dessa realidade. "Tudo é poesia, menos a poesia". Se ridiculariza e ridiculariza o próprio antipoeta, uma síntese de contrários "nem muito esperto nem doido varrido", "fui o que fui: uma mescla / de vinagre e azeite / um embutido de anjo e besta" (Poemas y antipoemas "Epitáfio" in: Obras completas \& algo + vol. I, p. 29). Numa autodefinição escorregadia e circular de 1985, escreveu

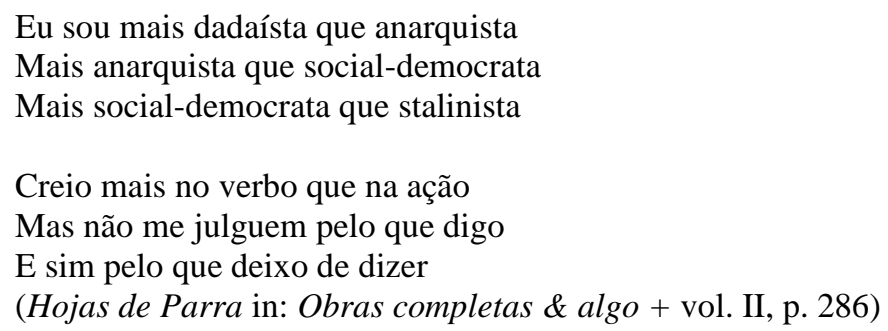

A relação de Parra com a política e as ideologias é, naturalmente, de uma profunda ambivalência. Como dadaísta e taoísta ${ }^{8}$, intui uma natureza essencialmente plural e contraditória da vida. A carga liberadora de seu riso almeja a demolição e questionamento de todo aprisionamento sistemático do real. A voz de Parra é uma voz dissidente, em tensão permanente com as diversas modalidades do poder. É um questionamento radical da validez dos "metarrelatos" ocidentais do século XX (com exceção, talvez, do ecologismo): escapismo religioso ou hedonista, arte pela arte, psicologismo, cientificismo, liberalismo, comunismo... No final de um poema escrito na década de 1950, escreveu que "O Ocidente é uma grande pirâmide / Que termina e começa num psiquiatra: a pirâmide está por derrubar" (Obra gruesa "Siegmund Freud" in Obras completas \& algo + vol. I, p 221). Parra pretendia expressar o que ele

\footnotetext{
8 Tristan Tzara várias vezes associou o Dada ao Tao: "Chuang Tsu era tão Dada quanto nós" (TZARA, 1996, p. 391). Também o filósofo da ciência Paul Feyerabend, que juntamente com o "colega anarquista" Imre Lakatos eram admirados por Parra, se identificava "como um dadaísta irreverente e não como um anarquista sério" (FEYERABEND, 1977, p. 26).
} 
teorizava como "crise do logos ocidental" chamada ingenuamente por alguns de "fim da história/fim da arte", mas que ele via como uma profunda crise discursiva (PARRA, 2012, p. 1119). As alusões e posicionamentos político/ideológicos de um falante (antipoeta) de tal composição e temperamento instável e imprevisível (quântico) são feitas para chocar ${ }^{9}$.

Em 1962, Nicanor Parra profere o "Discurso de bievenida en honor de Pablo Neruda" na Universidade do Chile. Como em diversas outras ocasiões, ele insiste no desconforto e na incapacidade do poeta "em pensar com cabeça e não com coração" e, falando de si próprio, aponta a contradição entre o discurso acadêmico com o

\begin{abstract}
temperamento fragmentário e díscolo do antipoeta. A antipoesia é uma luta livre com os elementos, o antipoeta concede a si mesmo o direito de dizer tudo, sem cuidar em nada das possíveis consequências práticas que podem lhe acarretar suas formulações teóricas. Resultado: o antipoeta é declarado persona non grata. Falando de peras o antipoeta pode sair perfeitamente bem com maçãs, sem que por isso o mundo venha abaixo. E se vem abaixo, tanto melhor, essa é precisamente a finalidade última do antipoeta, arrebentar na base do murro os fundamentos carcomidos das instituições caducas e estagnadas.
\end{abstract}

Neste discurso Parra faz uma penetrante análise da significação e influência da aventura existencial de Neruda em seu próprio espírito. Para ele, a obra de Neruda não poderia ser reduzida meramente ao plano das imagens poéticas

Pois sua poesia está mais próxima do sangue que da tinta e constitui uma componente importante do pensamento revolucionário do século XX. Por isso não se pode falar de Neruda em abstrato, porque ele não é um poeta de salão nem um buda absorto na contemplação do umbigo.

Parra ainda enxergava pontos de solidariedade entre a anárquica posição antipoética e o projeto socialista que Neruda encarnava como "poeta soldado":

9 Ao discorrer sobre o termo fundamental - e virtualmente intraduzível - do budismo, o dharma "doutrina, conduta, virtude, essência, fenômeno, constituinte último", Paz escreve que "a atividade dos dharmas é o tecido da tela quimérica que chamamos realidade. Mas os dharmas são um suporte instável: são instantâneos e relativos. Não tem ser e tampouco não-ser (nisso poderiam parecer com as partículas atômicas da física atual)" (PAZ, 1996, p. 27) 
Talvez o método de combate seja, apesar de tudo, onde se inscreve a diferença entre o poeta soldado e antipoeta: o antipoeta se bate à base de murros, em circunstâncias onde o poeta soldado não dá um passo sem sua metralhadora portátil. Por razões de caráter pessoal o antipoeta é um francoatirador. Luta pela mesma causa, mas com um método completamente distinto, sem negar o poeta soldado, combatendo com ele desde longe, mesmo que seu método possa parecer ambíguo (PARRA, 2011, p. 717).

Até o final da década de 1960, Parra ainda era bastante apreciado pela esquerda intelectual chilena e latino-americana (dando recitais e viajando diversas vezes para os EUA e a Inglaterra, mas também para Cuba, Praga, China e URSS, onde, em 1964, publica uma antologia bilíngue Poesía soviética rusa). Em 1969, Parra ganha o Prêmio Nacional de Literatura por haver "interpretado o gênio popular e os sentimentos do homem contemporâneo" (BINNS, 2006, p. LVI). Mas não eram tempos fáceis para franco-atiradores. Depois de um surpreendente repouso da agressividade antipoética representada pela obra Canciones rusas (1967), com La camisa de fuerza (1969) o antipoeta volta ao ataque contra as máquinas de opressão e alienação do ser humano, desta vez fustigando simultaneamente a Igreja Católica, os EUA e o Partido Comunista, como nos (anti)poemas que combinam tirocínio, blasfêmia, angústia e delírio "Ata de independência", "Telegramas" ou "Me retrato de tudo que foi dito". Numa entrevista de 1966, perguntaram a Parra qual seria para ele o "Inimigo Público Número Um”. Sem titubear, o antipoeta responde: "o Tonto Solene, seja de direita ou de esquerda" (PARRA, 2006, p. LV). Evidentemente, Nicanor Parra sempre havia sido crítico dos governos chilenos até a chegada ao poder de Salvador Allende (1908-1973), em 1970. A princípio a favor da Unidade Popular, aos poucos sua verve anarquista vai indispondo-o com os dois espectros do extremamente crispado ambiente político da época. Em algumas entrevistas dos anos sessenta, Parra tentava defender sua autonomia: "Sou um escritor de esquerda, considerado por muitos como comunista. Minha posição: franco-atirador não militante. Creio que o escritor é um país independente” (2006, p. LVIII).

A ruptura das suas relações com a esquerda intelectual latino-americana se deu de forma escandalosa após o célebre episódio do chá na Casa Branca. Em 15 de abril de 1970 - pouco antes do que seria uma viajem para participar como jurado da Casa das 
Américas em Havana - Nicanor Parra participou de um Encontro Internacional de Escritores, convocado pela biblioteca do Congresso, em Washington. Na inauguração desse evento vai, juntamente a outros escritores, a um "passeio cultural" na Casa Branca. Segundo conta o próprio Nicanor (2006, p. 974), Pat Nixon - esposa do contestadíssimo presidente Nixon - aparece inesperadamente e recepciona o grupo com música de câmara, chá e um exemplar das obras completas de Elizabeth Bishop (19111979). As fotos e repercussões do caso têm um efeito devastador nos ânimos políticos exaltados da época. Vários intelectuais de esquerda hostilizam Parra duramente. Cuba retira seu convite para participar como jurado na Casa das Américas. O intelectual cubano Roberto Fernández Retamar (1930-2019) publica uma nota na qual diz: "profundamente afetado. Apelo à justiça revolucionária. Solicito a reabilitação urgente. Viva a luta anti-imperialista dos povos oprimidos, viva a Revolução Cubana!" (PARRA, 2006, p. 974). O próprio Pablo Neruda, ainda em 1966, fora acusado de “desvio ideológico e atividade contrarrevolucionária" pela famosa "Carta abierta de los Cubanos" - organizada por Roberto Fernández Retamar e assinada por dezenas de intelectuais entre os quais Alejo Carpentier (1904-1980) e Nicolás Guillén (1902-1989). Em seu livro de memórias, Neruda expressa toda sua raiva e desprezo envolvendo o evento - outro exemplo da intensidade dos "conflitos ideológicos" daqueles tempos (mesmo no campo das esquerdas) e escreve sobre Retamar:

\begin{abstract}
A verdade é que nunca o considerei um valor autêntico, apenas um a mais entre os arrivistas políticos e intelectuais de nossa época. [...] Cada um tem sua fraqueza. Tenho muitas. Por exemplo: não abro mão do orgulho que sinto por minha atitude inflexível de combatente revolucionário. Será talvez por isso, ou por outra fissura de minha pequenez, que tenho me negado até agora e continuarei me negando a dar a mão a qualquer um dos que, consciente ou inconscientemente, assinaram aquela carta que continua me parecendo uma infâmia (NERUDA, 2019, p. 392). ${ }^{10}$
\end{abstract}

${ }^{10}$ Décadas mais tarde, Retamar criticaria duramente Octavio Paz acusando-o de ser "junto de Mario Vargas Llosa, o não-presidente do Peru, o outro grande porta-voz da direita latino-americana", comparando veladamente as críticas ao socialismo autoritário então feitas por Paz com o devir fascista de José Vasconcelos (FERNÁNDEZ RETAMAR, 2006, p. 52). 
A "excomunhão cubana" afeta profundamente os ânimos de Nicanor Parra, que experimenta um isolamento e ostracismo dilacerante: "me cortaram uma asa, agora sou uma ilha bloqueada por Cuba", escreve. Organizam-se boicotes às suas aulas de mecânica teórica. Jorge Edwards conta que, nesses dias, alguém diz ter visto um solitário Nicanor no pátio da faculdade onde ensinava as teorias de Newton e Einstein sentado num banquinho de madeira e com um pequeno cartaz escrito à mão: "Dou explicações". Ninguém apareceu. O presidente da Sociedade de Escritores do Chile Merino Reyes publica um artigo exigindo retratação e qualificando-o de "hippie sexagenário". Nicanor responde com uma carta pública afiadíssima e muito esclarecedora sobre as figuras do "energúmeno" e do "tonto solene" tão presentes em sua obra.

Numa longa entrevista com Iván Carrasco gravada em 1983, Nicanor confessa que foi nesse ano de 1970, em uma viagem aos EUA, que sentiu por primeira vez o "alarme ecológico" que posteriormente desembocaria nos seus "ecopoemas". Parra afirma com orgulho que foi entre os "hippies de Nova York meus companheiros" e em recitais ao lado do amigo e poeta anarquista Allen Ginsberg (1926-1991) ${ }^{11}$ que iniciou seu "trabalho ecológico" e lamenta:

Eu cometi a torpeza, a estupidez, de não seguir essa linha, e permaneci calado sobre o tema. Porque cheguei ao Chile e aqui estava a Unidade Popular e quando eu falei da ecologia me disseram que era a nova máscara do imperialismo, de maneira que fiquei calado (CARRASCO, 2007, p. 72).

Nesta conversa com Iván Carrasco, Parra afirma que o torvelinho dos acontecimentos políticos da década lhe causou muito sofrimento e que foi uma época bastante difícil ${ }^{12}$ somente logrando "recuperar o caminho perdido" muitos anos depois

\footnotetext{
${ }^{11}$ Nicanor Parra manteve relações com vários poetas do chamado movimento beat. O também anarquista Allen Ginsberg se hospedou em sua casa no Chile e influenciou Parra na apreciação de filosofias orientais como o budismo tibetano e o Tao.

12 Ao comentar o famoso poema "Homem imaginário" (concebido em 1978), Parra confessa que sua dor provinha de um amor realmente trágico: "Essa é uma coisa que ocorreu... Eu tinha sessenta e quatro anos e ela trinta e dois. E ela era a mulher que eu sonhava e que buscava e que acreditava ter encontrado [...]. Ela era casada, tinha dois filhos. Ela se suicidou [...] E eu, graças ao taoísmo, sobrevivi" (PARRA, 2012, p. 1054).
} 
(início da década de 1980) com a descoberta de uma nova "arma filosófica", o taoísmo, que define então como "a ecologia do mundo interior e desde aí, o salto, a passagem ao taoísmo da natureza que é a ecologia" (CARRASCO, 2007, p. 21).

Mas naquele então (anos pré-golpe), sua situação solitária - um documento das relações tensas da intelectualidade latino-americana num contexto extremamente ideologizado - empurrou ainda mais a antipoesia parriana rumo ao riso escrachado e a uma careta cada vez mais tortuosa. Essa raiva desenganada e irada foi plasmada de forma lapidar no livro Emergency Poems (1972), no qual encontram-se, segundo Miller Willians, "os melhores poemas de sátira social de qualquer época” (PARRA, 2006, p. 973), tais quais "Como lhes ia dizendo", "Se o papa não rompe com USA", "Então", "Viva Stálin", "Moscas na merda", "Como disse Marcuse", "Tempos modernos", “Perguntas e respostas", "Passatempos”, "Eu Jeová decreto" e

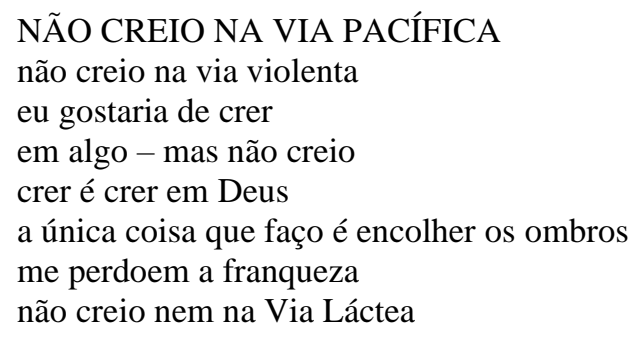

(PARRA, 2006, p. 283)

Neste ponto, a antipoesia parece ter alcançado seu ponto máximo de desemparo (incerteza/relatividade), de niilismo e ironia corrosiva que nada poupa, alterando adesão e dissidência, entusiasmo e indignação, mesmo às bandeiras biograficamente caras: fé humanista, prática da ciência, vocação poética, surrealismo, marxismo, anarquismo e à própria antipoesia. A inimizade e ruptura com amplos setores da esquerda chilena e latino-americana se aprofundaram com o surgimento dos Artefactos (1972). Provavelmente nós, brasileiros, temos dificuldade em ter ideia da provocação suscita pela publicação desses "materiais" no agitadíssimo ano que antecedeu o golpe militar de Augusto Pinochet. Em 1973, os militares mandam destruir grande parte das caixas editadas pela Universidade Católica. Nicanor Parra lembra um episódio esclarecedor. Certa vez, ao ser perguntado pelas razões do golpe, o reitor-interventor almirante Jorge 
Swet colocou sobre a mesa um caixa do Artefatos e disse: "Para que isso não ocorra nunca mais”. Depois, mandou queimar tudo.

A 'incorreção' política dos Artefactos foi recebida em termos duríssimos pela imprensa cultural chilena. O jornal Puro Chile, por exemplo, publica um artigo intitulado "Os artefatos de Nicanor Parra: uma exposição de seu verdadeiro pensamento político", no qual considera suas invenções antipoéticas como uma "coleção de cartões postais expressamente editados para atacar as forças da esquerda [...] seguramente (os artefatos) terão brilhante recepção nos bairros snob [...] os fascistas não poderiam ter melhor propagandista que Parra neste momento" (PARRA, 2006, p. 995). Julio Huasi culpa o "anarquismo desesperado" e o absolutismo de seu relativismo e ceticismo pela transformação de Parra num "ente ideologicamente abortivo", cruelmente especulando que Violeta Parra (1917-1967) seguramente ficaria repugnada e envergonhada perante a "risada amoral e agnóstica" do irmão mais velho, projetando hipoteticamente na falecida cantora uma "enfuturada" partícipe da "luta armada contra o imperialismo" em oposição ao "des-revolucionário" antipoeta (PARRA, 2006, p. 994). Ele, que no belíssimo "Defesa de Violeta Parra" (1969) escrevera "eles te acusam disso e aquilo / eu te conheço e digo quem tu és / ó cordeirinho disfarçado de lobo!"13

Durantes os piores anos da longa noite que se abateu no Chile sob a ditadura militar, o ostracismo de Nicanor se intensificou. "Depois de 1973 eu não contava nem com a ditatura nem com a revolução" (PARRA, 2006, p. 1031). A esquerda acusa o antipoeta de colaboracionismo com o regime. Elementos da extrema direita atacaram violentamente várias vezes suas residências, "durante anos cagavam todas as noites na minha porta" (PARRA, 2006, p. 1031). ${ }^{14}$ Em 1977, o Teatro La Feria lança um ousado (anti)espetáculo baseado em textos de Hojas de Parra com críticas oblíquas à ditadura. O protagonista era um (anti)canditado à presidência chamado Ninguém que fazia intermináveis promessas: "Ninguém solucionará nossos problemas. Ninguém se

\footnotetext{
${ }^{13}$ Neste poema, qualquer vestígio de parodia está ausente e a atmosfera é de uma gravidade contagiante e muito triste. A relação estreita entre os irmãos Parra é narrada na bonita autobiografia Décima, na qual a cantora diz "sem Nicanor não há Violeta".

14 Em 1985, a casa de Nicanor Parras em Las Cruces foi completamente incendiada por agentes clandestinos da ditadura.
} 
preocupará com os direitos humanos...". O cenário era um circo miserável que ficava ao lado de um cemitério coberto de cruzes e mortos. O diário La Segunda, órgão simpático ao regime militar, considerou a peça "a mais incrível e insolente crítica contra nosso movimento, contra o 11 de setembro e contra quem - num supremo esforço livramos esse país das garras do marxismo" (PARRA, 2006, p. LXIV). O espetáculo foi proibido pelas autoridades e a tenda circense foi incendiada numa madrugada. Como muitos escritores que pretendiam driblar a censura, Parra buscou seu refúgio sob a máscara de um estravagante místico popular da década de 1930, Domingo Zárate Vega, autointitulado "Cristo de Elqui" e publicou, entre 1977 e 1979, dois volumes dos Sermones y prédicas del Cristo de Elqui. A estratégia comunicacional do antipoeta consistia em se esconder atrás da voz delirante do iluminado popular para destilar toda sorte de críticas que fundiam antipoesia, anarquia e cultura popular.

\section{O magnetismo da tradição libertária}

Os surrealistas viveram, então, na convicção de que a revolução social estendida a todos os países não podia deixar de promover um mundo libertário (alguns diziam, um mundo surrealista, mas é a mesma coisa). [...] Sabe-se muito bem que impiedosa pilhagem foi feita dessas ilusões durante o segundo quartel deste século. Por uma terrível ironia, ao mundo libertário com o qual se sonhava, substituiu-se um mundo onde a mais servil obediência é obrigatória, onde os direitos mais elementares são negados ao homem, onde toda a vida social gira em torno do policial e do carrasco. Como em todos os casos em que um ideal humano chega a esse cúmulo de corrupção, o único remédio é refortalecer-se na grande corrente sensível onde se originou, retornar aos princípios que lhe permitiram constituir-se. É no próprio fim desse movimento, hoje, mais do que nunca necessário, que se encontrará o anarquismo, somente ele.

André Breton, A Clara Torre, 1952

O ressurgimento de meus velhos mestres me excita e me exalta: Bakunin, Fourier, os anarquistas espanhóis. E com eles o retorno dos poetas videntes: Blake, Rimbaud etc. A grande tradição que vem do romantismo alemão e inglês para o surrealismo. É minha tradição.

Octavio Paz, 1968

Ao contrário de Parra, Octavio Paz evitava afirmar cabalmente ser um anarquista. Mas diversas vezes expôs seu fascínio e o influxo do que ele mesmo chama "tradição libertária e anarquista" (PAZ, 1995, p. 39) sobre seu pensamento político e sobre suas concepções de arte. Em 1990, Paz escreve que "as doutrinas anarquistas e socialistas foram o grande fermento político e social do século XIX" e que os "regimes 
totalitários surgidos pela versão bolchevique do marxismo foram o tiro pela culatra do socialismo". Ele nega que esses regimes tenham sido "socialistas ou científicos" e não considera que o descrédito desse "terrível experimento" alcançaria também as

\footnotetext{
aspirações libertárias e igualitárias que inspiraram os pensadores anarquistas e socialistas do século XIX. Ante as iniquidades do sistema capitalista esses homens se fizeram algumas perguntas. Estas perguntas seguem sem respostas. [...] Quase seguramente, nossas respostas serão distintas. Nada mais natural. Mas estarão inspiradas por motivos semelhantes e deverão satisfazer esperanças análogas (PAZ, 1990, p. 222).
}

No extenso prólogo do livro Ideas y costumbres I (escrito em 1993), ao refletir sobre seu "itinerário" político e intelectual, Paz volta sua análise para questões que sempre o afligiriam e fascinaram: "a exploração dos vastos e confusos territórios, sempre em movimento, da literatura e da arte" e, mais especificamente, as posições ideológicas assumidas por artistas e intelectuais frente à "terrível história do século XX" (1995, pp. 15-18). Particularmente lhe interessa refletir sobre a ambivalente ideia da Revolução que seria, segundo ele, "paixão generosa e fanatismo criminoso, uma iluminação e uma obscuridade" (1995, p. 17).

Ao refazer seus "primeiros passos", ele fala da sua amizade adolescente com José Bosch "e sua incansável fidelidade aos ideais libertários [...] a ele devo minhas primeiras leituras de autores libertários (seu pai era militante da Federação Anarquista Ibérica)" (1995, p. 18). Assim como o amigo Bosch, Paz também associa sua inquietação intelectual à trajetória do pai, um advogado que se juntou aos campesinos do movimento zapatista de Morelos. Octavio Paz afirma que "viveu esta Revolução desde minha infância. [...] A Revolução Mexicana foi um inesperado rebrotar de uma velha raiz comunitária e libertária” (1995, p. 107). Em sua primeira juventude, Paz e Bosch (mais tarde expulso do México) participaram de protestos acadêmicos e manifestações de rua, sendo detidos pelas forças policiais e "resgatados" pelo advogado zapatista Paz Solórzano. "Bakunin, Fourier e os anarquistas", destaca Enrique Krauze, "foram os primeiros mentores políticos de Octavio, mas logo ele foi "salvo", no jargão da época, pelo marxismo" (2011, p. 169). 
Em 1937, recém-casado com a escritora Elena Garro (1916-1998), Paz junta-se à um grupo de "agitadores culturais" mexicanos (entre os quais o poeta Carlos Pellicer (1897-1977) e o compositor Silvestre Revueltas (1899-1940), irmão mais velho de José Revueltas (1914-1976) ${ }^{15}$, que zarpa rumo à convulsionada Espanha para, com palavras e feitos, participar da "poesia da História" no Congresso de Escritores Antifascistas. A visão e participação na Guerra Civil espanhola - a comunhão com a potência da resistência rebelde das pessoas, bem como a crueldade de seu complexo xadrez político e militar -, deixou marcas profundas na consciência política de Paz. Em Barcelona, inesperadamente, reencontra seu amigo anarquista José Bosch, que ele acreditava morto, num recital no qual Paz leu o poema "Elegía a un compañero muerto en el frente de Aragón”. Dele, teve chocantes informações sobre os confrontos que opuseram socialistas do POUM (majoritariamente trotskistas) e os anarquistas da CNT contra os "comunistas": "Eles mataram meus camaradas... eles mataram, eles mataram! Os comunistas!" (KRAUZE, 2011, p. 186), se indignava Bosch ${ }^{16}$ nos mesmos dias que George Orwell (1903-1950) descreveria no seu Homenagem à Catalunha (1938).

Durante sua juventude, como tantos outros de sua geração, Paz tentou borrar a oposição entre a poesia e a prática revolucionária, "facetas de um mesmo movimento, asas de uma mesma paixão" (PAZ, 1995, p. 19). Provem dessa visão seus profundos laços de afinidade com o movimento surrealista, particularmente com Benjamin Péret (1899-1959) ${ }^{17}$, Luis Buñuel (1900-1986) e André Breton (1886-1966), que conheceria pessoalmente na década de 1940. Paz escreveu muito sobre Breton e sua visão do surrealismo como uma "uma via revolucionária" que buscou suas fontes "no comunismo e na tradição libertária, entre os heterodoxos do cristianismo e entre os excêntricos da literatura, na rua e nos manicômios, no ocultismo e na magia, neste

\footnotetext{
15 No post scriptum do Labirinto da solidão, escrito em 1969, Paz denuncia a prisão de centenas de estudantes e professores dentre os quais José Revueltas "um dos melhores escritores da minha geração e um dos homens mais puros do México" (PAZ, 1992, p. 208).

16 Especula-se que o misterioso militante anarquista José Bosch (1910-1998), durante muito tempo considerado morto pelos fascistas espanhóis, na verdade conseguiu escapar levando uma vida de fugitivo até a caída de Franco, quando retornou à Espanha.

17 Perét foi militante trotskista e combateu Franco na divisão anarquista de Buenaventura Durruti (POLIZZOTTI, 2009, p. 424). Sobre o "incorruptível" surrealista francês, Paz escreve que "graças a homens como Perét a noite do século não é absoluta” (PAZ, 2001, p. 51).
} 
mundo e em outros... e nunca a encontrou" (1995, p. 38) Assim como o Dada, é na tradição e no pensamento vivificantes do anarquismo que o surrealismo mergulha suas raízes $^{18}$. O próprio André Breton reconhece a identidade entre anarquismo e surrealismo, quando reflete em $1952^{19}$ sobre as origens e destinos do surrealismo:

Foi no negro espelho do anarquismo que o surrealismo se reconheceu pela primeira vez, bem antes de se definir a si mesmo e quando era apenas associação livre entre indivíduos rejeitando espontaneamente e em bloco as opressões sociais e morais de seu tempo. [...] Por que uma fusão orgânica não pode se operar nesse momento (década de 1920) entre elementos anarquistas propriamente ditos e elementos surrealistas? Ainda estou, vinte e cinco anos depois, a me perguntar (COELHO, 1990, p. 27).

Harold Bloom, que considerava Paz o "maior homem das letras" do México, se impressionava com a singularidade da sua escrita que definia como uma espécie de amálgama de misticismo erótico sumamente individualizado, hermetismo e Romantismo ocidentais e um "surrealismo com raízes orientais e astecas” (2003, p. 558). Se em Parra encontramos uma espécie de continuum entre a antipoesia (riso absurdista, autosarcasmo e escracho), dadaísmo, anarquia e individualismo, a relação de Paz com o surrealismo também é evidente. Num antidiscurso sobre Vicente Huidobro (1893-1948), o primeiro antipoeta também admirado por Paz, Nicanor Parra cita explicitamente a "plataforma de luta", de Max Stirner (que já não lhe chama tanto a atenção como antes) e remete aos provocadores pensamentos do autor de Altazor: "Quem tiver estudado a fundo/o mundo atual/não pode deixar de se tornar comunista/quem tiver estudado a fundo/o partido comunista/não pode deixar de se tornar anarquista" (PARRA, 2012, p. 651) A contra-di(c)ção da antipoesia parriana

\footnotetext{
${ }^{18} \mathrm{O}$ diálogo e a tensão entre surrealismo e anarquismo foi notada por Walter Benjamin: "Nas correntes literárias do terceiro decênio (do século XX) atuava sempre de novo, decisivamente, o anarquismo: a crescente superação do anarquismo caracterizava o caminho do surrealismo, de seus primórdios até o presente" (BENJAMIN, 1985, p. 183). Michael Löwy, no seu estudo sobre as relações entre a "carga mágica, embriagadora e libertária do surrealismo" e o "marxismo libertário", analisa as opiniões e posições de Walter Benjamim que se enxergava "situado em uma posição infinitamente perigosa entre a fronda anarquista e a disciplina revolucionária" e que também escreveu que "depois de Bakunin, faltou à Europa uma ideia radical de liberdade. Os surrealistas têm esta ideia" (LÖWY, 2002, p. 44).

${ }^{19}$ A colaboração de Breton com o periódico anarquista Le Libertaire (1951 e 1952) e, particularmente, o artigo aqui citado "A clara torre", segundo Mark Polizzotti, fornece "uma comovedora descrição da perene atração do surrealismo pelo anarquismo" (2009, p. 552).
} 
sempre criticou o esgotado e colonizado surrealismo de "segunda mão" realizado na América Latina, mas é verdade que ele também foi bastante mais influenciado pela nova dicção encontrada pela voz surrealista, principalmente em alguns poemas anteriores à década de 1950 e mesmo em alguns poemas de sua mais impactante obra Poemas \& antipoemas de $1954^{20}$. Por sua vez, a sempre penetrante intuição da inteligência de Paz foi capaz de iluminar aspectos da "antiobra" do mais genuíno gênio engendrado pelo espírito anarquizante do Dada no ensaio Marcel Duchamp (1887-1968) ou o castelo da pureza, escrito no ano da morte do artista francês.

Num texto escrito em 1996, Paz relembra suas relações com o surrealismo - "a enfermidade poética do nosso século" - e sua amizade com André Breton. Como acontecia em alguns de seus escritos, temos a impressão de que ao falar de um personagem que lhe tocava e fascinava, Paz na verdade refletia sobre si próprio. Várias de suas expressões sobre Breton - "rebelde que nega a autoridade"; "habitado sempre pelos contrários: a selva e a cidade, o passado e o futuro, el más allá y el más acá"; "revolucionário, se forjou numa tradição que não é a de todos: a família dos grandes heresiarcas [...] Conviveu com eles e entre eles sem tentar conciliação" -, bem poderiam ser aplicadas a si mesmo. Se ao final de sua vida Nicanor Parra esboça um riso dadaísta/taoísta ao propor como "tarefa de casa / aprender a viver na contradição / sem conflito", homens como Breton e Paz mergulharam em ressentimentos, decepções melancólicas e conflitos "que não foram realmente contradições; não pertenciam ao reino da lógica senão ao misterioso subsolo psíquico" mesclando iluminação e desespero, exaltação e abatimento, adivinhações e contradições, "niebla y relámpago". Almas cindidas? Homens partidos? Paz termina falando de seu amigo-alter-ego em termos de uma dialética que lembra um Tao malogrado: "Não quis ou não pôde

\footnotetext{
${ }^{20}$ Em seu estudo sobre o surrealismo na poesia da América Latina, Floriano Martins cita Paz sugerindo que a relação da poesia hispano-americana com as vanguardas europeias tendia à imitação, exceto por alguns "poetas de minha geração: Lezama Lima, Nicanor Parra, Enrique Molina, Alberto Girri, Vitier e alguns poucos mais" (MARTINS, 2001, p. 17). Por sua vez, Parra cita Paz no seu Discurso de Guadalajara (1991), ao receber o Prêmio Juan Rulfo, sugerindo total identificação entre sua apreciação da obra de Rulfo com as opiniões de Paz sobre o mesmo: "Rulfo nos da una imagen de México/Los demás se reducen a describir el país/A eso se refiere Paz/Cuando digo que Juan hay uno solo" (PARRA, 2011, p. 563).
} 
conciliar os opostos (quem pôde?) mas com a mesma decisão e valentia espiritual saltou do sim ao não e do não ao sim. No seu Sim cabem muitas negações; no seu Não muitas afirmações" (PAZ, 2001, p. 38).

Ao relembrar esses anos de formação e crise "moral e intelectual" (desilusão gradual e traumática com o socialismo soviético), Paz dizia palmilhar o "caminho dos solitários", um punhado de intelectuais que "vagamente poderíamos chamar de oposição de esquerda" e que eram fustigados por inimigos unidos "direita e comunistas" em seu "ódio comum à crítica e à independência" (PAZ, 1995, p. 41). A primeira figura evocada, ao passar em revista as décadas de 1940 e 1950, é a do dissidente russo Victor Serge (1890-1947). Paz ficou muito comovido com a personalidade e inteligência "sem dúvida devida a suas origens anarquistas e a seu grande coração" do velho revolucionário que lhe abriu novas perspectivas e que "com seu exemplo me mostrou que não basta mudar as ideias: há que se mudar de atitudes. Há que mudar de raiz" (1995, p. 33). Também muito importante, foi a descoberta e leitura sistemática de George Orwell "guiado por sua linguagem precisa e por seu nítido pensamento, pude enfim pisar em terra firme" (1995, p. 33) e as conversas e relações mantidas com o intelectual grego Kostas Papaioannou (1925-1981), que apresentaria Paz ao "filósofo da autonomia" Cornelius Castoriadis (1922-1997). Em 1951, Paz conhece Albert Camus (1913-1960) que estava a ponto de publicar o seu $O$ Homem Revoltado: "O que nos uniu, primeiramente, foi nossa fidelidade à Espanha e a sua causa. Através de seus amigos espanhóis, ele havia redescoberto a tradição libertária e anarquista; por minha parte, também eu havia voltado a ver com imensa simpatia essa tradição” (1995, p. 39). E continua:

Breton ou a rebeldia; Camus ou a revolta. Como indivíduo, sinto-me mais próximo da primeira; como homem social, da segunda. Meu ideal, inalcançável, foi ser um semelhante entre meus semelhantes. O rebelde é quase sempre um solitário; seu arquétipo é Lúcifer, cujo pecado foi preferirse a si mesmo. A revolta é coletiva e seus seres são homens comuns. Mas a revolta, como as tormentas de verão, se dissipa rapidamente: o seu próprio excesso de fúria justiceira a faz explodir e dissolver-se no ar (1995, p. 40). 
Quando Paz leu O Homem Revoltado de Camus ficou bastante impressionado com a beleza de sua expressão e pela ideia, que adotaria mais tarde, de uma revolta fundada na "mesura mediterrânea", o chamado "pensamento do meio-dia", que não significaria simples moderação "mas sim equilíbrio dos contrários cuja forma mais alta é o ato heroico que diz Sim ao destino. Entrever o sentido dessa mesura é começar a recobrar a saúde psíquica e política" (1995, p. 40). O segredo e a chave para alcançar essa "mesura", que Paz retornaria a partir dos anos 1980, estaria na realização da síntese entre duas tradições da modernidade Ocidental: o liberalismo (aspiração de liberdade) e o socialismo (aspiração de igualdade). Essa seria a grande questão, na opinião de Paz, que o pensamento crítico do século XXI enfrentaria (1995, p. 60).

Durante a década de 1950 e início da 1960, Paz aprofundava sua investigação sobre a "verdadeira natureza do socialismo", mas sem vislumbrar a possibilidade de um socialismo antiautoritário, como o defendido por Orwell, triunfar. Como Nicanor, ainda se via como um homem de esquerda e socialista. Mas se colocava numa posição, não tão comum em tempos Guerra Fria, de "socialista independente", outro "francoatirador".

No poema "Canción Mexicana" (Ladera Este, escrito na Índia no início da década de 1960), Paz exprime seu sentimento de orfandade em relação à linhagem revolucionária de sua família que "cheirava a pólvora". Enquanto avô e pai (este ao lado de anarquistas e zapatistas como os irmãos Flores Magón) engajaram-se em grandes eventos revolucionários da história mexicana, Paz se lamenta perante o dilema de sua vida política paralisada e inerme.

\section{Canção mexicana}

Meu avô, enquanto tomava sua xícara de café, me falava sobre Juarez e Porfirio, os zuavos e os prateados.

E a toalha da mesa cheirava a pólvora.

Meu pai, enquanto tomava sua taça de vinho, me falava sobre Zapata e Villa, Soto y Gama, e os Flores Magón. 
E a toalha de mesa cheirava a pólvora.

Eu me mantinha em silêncio.

Sobre quem eu poderia falar? $?^{21}$

O vendaval libertário que varreu diversas sociedades ocidentais no mítico ano de 1968, atingiu a letárgica crise filosófica e existencial que Paz experimentava então. Parecia agora que uma nova "revolução" lhe chamava a participar com as únicas armas que conhecia e valorizava: as palavras e as atitudes críticas. Pouco após o massacre de mais de trezentos estudantes perpetrado de forma abjeta pelo Exército Federal em Tlateloclo, Paz se desliga da sua carreira diplomática de décadas em repúdio e denúncia contra a violência e autoritarismo do Estado mexicano e do PRI. Essa atitude corajosa teve um impacto considerável entre a intelectualidade latino-americana.

Certos aspectos da revolta juvenil dos anos 1960, faziam Paz recordar os elementos antifascistas da 1930 e intensificaram o anseio de Paz de revisitar suas origens anarquistas (seu amigo Bosch) antes de se tornar um "marxista convicto". Em junho de 1968, Paz escreveu numa carta para o poeta inglês Charles Tomlinson (19272015):

A ordem medíocre do mundo "desenvolvido" está balançando. O ressurgimento de meus velhos mestres me excita e me exalta: Bakunin, Fourier, os anarquistas espanhóis. E com eles o retorno dos poetas videntes: Blake, Rimbaud etc. A grande tradição que vem do romantismo alemão e inglês para o surrealismo. É minha tradição. Charles, a poesia está se transformando em ação. Acho que estamos no ponto de saída do túnel, deste túnel que começou com a queda da Espanha, com os julgamentos de Moscou, com a ascensão de Hitler, o túnel cavado por Stálin e que os Eisenhower, os Johnson e os tecnocratas capitalistas e comunistas nos disseram que era o caminho para o progresso e o bem-estar. Qualquer que possa ser o resultado imediato da crise francesa, estou certo de que algo se iniciou em Paris que mudará decisivamente a história da Europa e, talvez, do mundo. A verdadeira revolução socialista - Marx estava certo sobre isto - só pode acontecer nos países desenvolvidos. O que ele não disse (embora, depois da Comuna de Paris, ele parcialmente aceitou) foi que a revolução deveria ser socialista e libertária. O que está agora se iniciando não é a crise do capitalismo e as caricaturas sombrias do socialismo que são a União Soviética e seus satélites e rivais (a China delirante de Mao) - é a crise do

${ }^{21}$ Esta versão em português foi retirada do livro de Enrique Krauze (2011, p. 143) com tradução de Magda Lopes, Cecília Dourado e Gabriel Federicci. 
mais velho e mais sólido instrumento de opressão que os homens já conheceram desde o fim da era neolítica: o Estado (KRAUSE, 2011, p. 246).

Paz ruminaria os significados da dramática experiência espanhola por longos anos, atormentado por não ter podido enxergar, ainda naquela época, o "lado obscuro da Revolução" e o que chamaria, décadas mais tarde, apelando para um linguajar religioso, "pecado" e "abjeção" dos intelectuais que, como ele, foram vinculados ao comunismo soviético. As ambiguidades da Revolução e um profundo anticomunismo seriam os principais temas (quase uma obsessão) nas últimas três décadas de sua vida. Krauze recorda que ao lidar com o tema "suas palavras sempre exibiriam o peso de um profundo conflito religioso" (2011, p. 273) de alguém retorcido por um conflito, quase uma autopurgação. ${ }^{22}$

\section{Considerações finais}

Os anarquistas militantes costumam desdenhar dos anarquistas filosóficos, e é compreensível, ainda assim lamentável. Enquanto o anarquismo permanecer um movimento minoritário, um sentimento de conjunto favorável às ideias anarquistas, mesmo vago, cria um clima que faz com que se escute a propaganda e que o movimento possa desenvolver-se. Nicolas Walter, Do anarquismo

Com meus próprios olhos vi como os infrarrealistas (os sabotadores) jogaram o conteúdo de um copo em Paz (que estava lindíssimo, com um elegante blazer) e como o poeta sacudiu a gravata e prosseguiu sua conversa como se não tivesse acontecido nada, sorrindo. Carmen Boullosa, El agitador y las fiestas (2013, p. 439)

A escritora mexicana Carmen Boullosa escreve sobre a turbulenta cena cultural e literária mexicana do final dos anos 1960 e início dos 1970, quando pululavam os grupelhos literários de vanguarda, os talleres e revistas de poesia, as intrigas e os embates como por exemplo, entre os seguidores de Efrían Huerta (1914-1982) - outro

\footnotetext{
${ }^{22}$ Pode ser oportuno contrastar o dilaceramento espiritual de Paz com as impressões contidas na polêmica biografia de Nicanor Parra escrita por Rafael Gumuncio, na qual o biógrafo se debate entre a admiração e o horror desconcertante frente à figura "vampiresca" do antipoeta. Gumuncio descreve Parra (nos seus anos finais) do seguinte modo: "Vive no inferno, penso, ou no purgatório, esse senhor que faz piadas todo o tempo, que caminha como se estivesse dançando e odeia o patetismo existencial ou qualquer tipo de gravidade. Não descansa nunca, mesmo que esteja tranquilamente sentado frente ao vendaval do mar" (GUMUNCIO, 2018, p. 288).
} 
"filho da Revolução Mexicana"-, e os seguidores de Paz, que já havia rompido com a Revolução Cubana e cada vez mais afiava as suas críticas ao "socialismo autoritário": "Aqueles do bando de Paz chamavam os efrainitas stalinistas. Os efrainitas chamavam os octavianos de reacionários. Nenhum dos apelativos era totalmente preciso" (BOULLOSA, 2013, p. 432). Um desses grupos de guerrilha poética dos anos 1970 eram os infrarrealistas (talvez outro avatar tardio do dadaísmo a la mexicana), que posteriormente seriam imortalizados como realvisceralistas em Los detectives salvajes (1998), a magnética homenagem à sua geração "perdida" escrita por Roberto Bolaño (1953-2003) que, juntamente ao seu amigo Mario Santiago (Ulisses Lima em Los detectives salvajes), eram os "líderes" dos infrarrealistas. Seguidores convictos do espírito de contradição, anarquia e provocação de Nicanor Parra ${ }^{23}$, Bolaño e Santiago costumavam irromper nos encontros poéticos quando o "grandíssimo e irancudo Pazo algunos de sus exquisitos seguidores se aventuraba con un poema sobre el yin y el yang o la circularidade del tiempo" (VOLPI, 2013, p. 194) lançando bombas fétidas, chistes e consignas belicosas contra Paz que podiam ser pesadíssimas. Carmen Boullosa recorda, por exemplo, uma festa (ocorrida entre 1973 e 1976), na qual Bolaño, elenca os motivos de seu ódio à Octavio Paz:

seus nefastos crimes à serviço do fascismo internacional, seus péssimos montículos de palavras que risivelmente chama de "poemas", sua abjeta ofensa à inteligência latino-americana, aquela chateação de 'revista literária' que com cheiro de vômito se fazia chamar de Plural (BOULLOSA, 2013, p. 440).

A acusação de "fascista" irritava especialmente os velhos participantes e/ou testemunhas da Guerra Civil espanhola como Octavio Paz. Enrique Krauze (2011, p. 269), seu velho colaborador, conta como Octavio Paz se indignava tremendamente, em conversas íntimas, quando lhe negavam sua condição de "revolucionário". Paz sempre se referiu à direita com desprezo e mesmo algum asco e, até o final, se via como um

23 Segundo o escritor Jorge Volpi, os infrarrealistas seriam "imitações" de enragés e situacionistas franceses e dos angry young men britânicos e "jipis gringos, y nadie se tomaba demasiado en serio sus exabruptos (excepto Paz, que solía tomarse un té de tila cada vez que pensaba en ellos)" (VOLPI, 2013, p. 194). 
homem da "esquerda intelectual", mas estava convencido de que "socialismo sem democracia não é socialismo" (KRAUZE, 2011, p. 267). Porém, foi com intelectuais desse campo que Paz travou suas últimas (e diversas) polêmicas: com Carlos Fuentes (1928-2012), Carlos Monsiváis (1938-2010) e o subcomandante insurgente $\operatorname{Marcos}^{24}$, por exemplo. Num comunicado de abril de 2000, Oximoron: la derecha intelectual y el fascismo liberal, Marcos se refere a ele como "o último grande intelectual de direita no México, Octavio Paz, que cumpriu cabalmente a tarefa encomendada pelo Príncipe" (EZLN, 2003, p. 438). Mas seria justo invalidar toda a obra de Paz por causa do seu apoio ao presidente Carlos Salinas de Gortari (ou mesmo de certos aspectos do neoliberalismo) nos seus últimos anos? O escritor mexicano Juan Villoro, apoiador dos zapatistas, considera que sem a figura de Paz, a cultura latino-americana e a poesia de língua espanhola ficariam mais pobres e sua imaginação crítica mais achatada. Paz, aos 80 anos de idade e acossado por seus demônios pessoais anticomunistas, não pôde ou não quis vislumbrar a potência e originalidade da insurgência dos zapatistas de 1994 que, paradoxalmente, iriam passar, nos anos seguintes à morte do poeta, por um processo de inflexão libertária e de crítica ao autoritarismo do Estado que ia de encontro com várias das suas melhores reflexões. Postura diferente assumiria o antipoeta chileno. No ano de 2010, aos 96 anos, Nicanor Parra foi um dos primeiros intelectuais chilenos a se juntar aos prisioneiros políticos mapuche (entre eles líderes da Coordinadora Arauco-Malleco) que aderiram à greve de fome que se prolongou por mais de 100 dias. "Esse é seu artefato", declararam à mídia seus familiares (MENARES, 2018). As demandas do protesto: restituição de terras e territórios, desmilitarização das comunidades e não aplicação da Lei Antiterrorista contra os militantes mapuche.

Muitos anarquistas creem que uma das principais potências do anarquismo residiria na sua capacidade de fermentar e fertilizar lutas e processos sociais e culturas

\footnotetext{
${ }^{24}$ As considerações de Paz sobre a insurreição do EZLN, muitas das quais descabidas (por exemplo, quando sugere que as origens ideológicas do neozapatismo deveriam ser buscadas no Sendero Luminoso), encontram-se em vários artigos do décimo quarto volume de suas obras completas. Sobre o subcomandante Marcos, que reconhece como grande talento intelectual, Paz escreve que: "La elocuente carta que el 18 de enero (1994) envió el "subcomandante” Marcos a varios diarios, aunque de una persona que ha escogido un caminho que repruebo, me conmovió de verdad: no son ellos, los indios de México, sino nosotros, los que deberíamos pedir perdón" (PAZ, 2001, p. 249).
} 
mais amplos. Como foi sugerido na epígrafe de Nicolas Walter que inicia este artigo, não pretendemos "rotular" ou "etiquetar" de forma superficial ou estanque pensadores tão complexos e extraordinários como Paz e Parra, mas sim notar algumas de suas evidentes "afinidades eletivas" ${ }^{25}$ " com a heteróclita gama de pensamentos e atitudes libertárias. Retomar os pensamentos, palavras, provocações, contradições e críticas de intelectuais que se deixaram (cada qual a seu modo e intensidade) influenciar pelo pensamento antiautoritário dos anarquistas pode ser muito proveitoso (mesmo quando não concordamos com eles); especialmente em nossos sombrios tempos de manipulação ideológica, onde as ideologias "conspiranóicas" da extrema-direita regurgitam autoritarismos e neofascismos (re)turbinados e (re)animados por diversas modalidades de estupidez, exploração e brutalidades assassinas.

\section{Referências bibliográficas}

ALEGRÍA, Fernando. Antiliteratura. In: MORENO, César Fernández (coord.). América Latina em sua literatura. São Paulo: Perspectiva, 1979.

ANTLIFF, Allan. Anarquia e arte: da Comuna de Paris à queda do Muro de Berlim. São Paulo: Madras, 2009.

BENJAMIN, Walter. Sobre a atual posição social do escritor francês. São Paulo: Editora Ática, 1985.

BINNS, Niall. Introducción. In: PARRA, Nicanor. Obras completas \& algo +: De "Gato en el caminho" a "Artefactos" (1935-1972). Volume I. Santiago de Chile: Círculo de Lectores, 2006

BLOOM, Harold. Gênio: os 100 autores mais criativos da história da literatura. Rio de Janeiro: Objetiva, 2003.

BOULlOSA, Carmen. El agitador de fiestas. In: PAZ SOLDÁN, Edmundo (org.). Bolaño salvaje. Barcelona: Candaya, 2013, p. 434-447.

CAPPELLETTI, Ángel. El anarquismo en América Latina. Caracas: Biblioteca de Ayacucho, 1990.

\footnotetext{
${ }^{25}$ O fecundo conceito de "afinidade eletiva" é utilizado por Michael Löwy (1989) no seu estudo sobre os cruzamentos, círculos e figuras do judaísmo libertário e anarquizante na Europa Central.
} 
CARRASCO, Iván. Nicanor Parra: documentos y ensayos antipoéticos. Santiago de Chile: Editorial USACH, 2007.

COELHO, Plínio (org.). Surrealismo e anarquismo: "bilhetes surrealistas" de Le Libertaire. São Paulo: Imaginário, 1990.

EZLN. Documentos y comunicados (1997-2000) vol. 4. México: Ediciones Era, 2003.

FERNÁNDEZ RETAMAR, Roberto. Pensamiento de nuestra América: autorreflexiones y propuestas. Buenos Aires: CLACSO, 2006.

FEYERABEND, Paul. Contra o método. Rio de Janeiro: F. Alves, 1977.

GUMUNCIO, Rafael. Nicanor Parra: rey y mendigo. Santiago de Chile: Ed. Universidad Diego Portales, 2018.

KRAUSE, Enrique. Os redentores: ideias e poder na América Latina. São Paulo: Saraiva, 2011.

LÖWY, Michael. Redenção e utopia: o judaísmo libertário na Europa Central - um estudo de afinidade eletiva. São Paulo: Companhia das Letras, 1989.

LÖWY, Michael. A estrela da manhã: surrealismo e marxismo. Rio de Janeiro: Civilização Brasileira, 2002.

MARTINS, Floriano. O começo da busca: o surrealismo na poesia da América Latina. São Paulo: Escrituras Editora, 2001.

MENARES, Felipe. "Economía mapuche de subsitencia": la receta de Nicanor Parra para supervivencia del planeta". El Ciudadano. Janeiro de 2018. Disponível em: https://www.elciudadano.com/chile/economia-mapuche-subsistencia-la-receta-nicanorparra-la-supervivencia-del-planeta/01/23/ Acesso em: 27 de abril de 2020.

NERUDA, Pablo. Confesso que vivi: memórias. Rio de Janeiro: Bertrand Brasil, 2019.

NETTEL, Guadalupe. Octavio Paz: las palabras en liberdad. Madri: Taurus, 2014.

PARRA, Nicanor. Obras completas \& algo +: De "Gato en el caminho" a "Artefactos" (1935-1972). Volume I. Santiago de Chile: Círculo de Lectores, 2006.

PARRA, Nicanor. Obras completas \& algo +: De "News from nowhere" a "Discursos de sobremesa”. Volume II. Santiago de Chile: Círculo de Lectores, 2012.

PASSETTI, Edson. Anarquismos e sociedade de controle. São Paulo: Cortez, 2003.

PAZ, Octavio. Chuang Tzu: un contraveneno. Madri: Ediciones Siruela, 2000.

PAZ, Octavio. Ideas y costumbres I: la letra y el cetro. Obras completas - Edición del autor (vol. 9). México: FCE, 1995.

PAZ, Octavio. Ideas y costumbres II: usos y símbolos. Obras Completas - Edición del autor (vol. 10). México: FCE, 1996. 
PAZ, Octavio. Miscelánea II. Obras Completas (vol. 14). México: FCE, 2001.

PAZ, Octavio. O labirinto da solidão e post scriptum. Rio de Janeiro: Paz e Terra, 1992.

PAZ, Octavio. La otra voz: poesía y fin de siglo. Barcelo: Seix Barral, 1990.

POLIZZOTTI, Mark. Revolución de la mente: la vida de André Breton. México: FCE, Turner, 2009.

RESZLER, André. La estética anarquista. Buenos Aires: Libros de la Araucaria, 2005.

ROSA, Luis Othoniel. Comienzos para una estética anarquista: Borges con Macedonio. Santiago de Chile: Editorial Cuarto Propio, 2016.

TZARA, Tristan. Conferência sobre o Dada (1924). In: CHIPP, H. B. Teorias da arte moderna. São Paulo: Martins Fontes, 1996, p. 389-393.

VARGAS, Sebastião; CAVALCANTE, Bárbara. Autoidentificação anarquista na literatura latino-americana do século XX. In: Actas del II Congreso Internacional de investigadorxs sobre anarquismo(s). Montevideo: CeDInCI, 2019, p. 988-1009.

VINCENT, Andrew. Ideologias políticas modernas. Rio de Janeiro: Jorge Zahar, 1995.

VOLPI, Jorge. Bolaño, epidemia. In: PAZ SOLDÁN, Edmundo (org.). Bolaño salvaje. Barcelona: Candaya, 2013, p. 187-204.

WALTER, Nicolas. Do anarquismo. São Paulo: Editora Imaginário, 2000. 